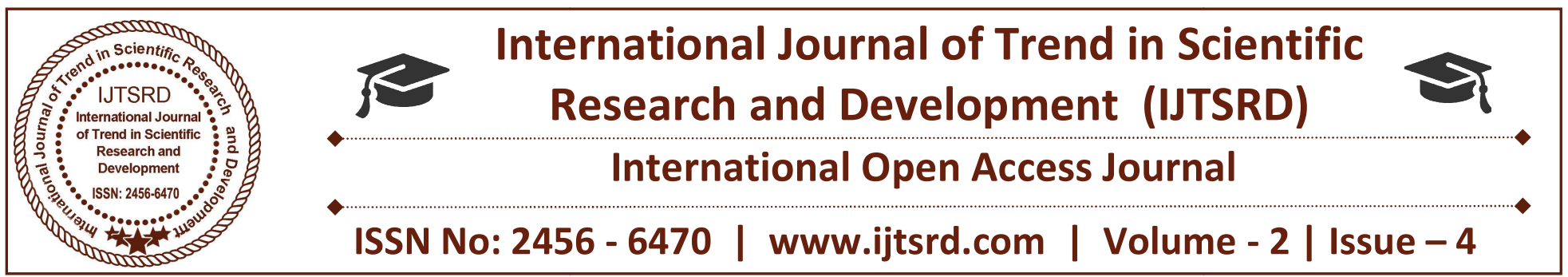

\title{
Effect of carbon dioxide on the performance of Spark Ignition Engine by Hydrogen Inject with Biogas Fuel
}

\author{
Keyur D. Patel \\ Department of Mechanical Engineering, \\ Vadodara Institute of Engineering, \\ Kotambi, Vadodara, Gujarat, India
}

\section{ABSTRACT}

Methane and carbon dioxide are the two main constituents of biogas. One of the reasons of poor combustion is the presence of carbon dioxide in the biogas. Biogas also has traces of nitrogen, hydrogen, oxygen and hydrogen sulphide. Because of a high investment cost and a heavy infrastructure, only fifty percent of the biogas production upgrades (decrease $\mathrm{CO} 2 \%$ ) by use of water scrubber. so the natural gas replacement is very low. This experiment is conducted on modified single cylinder $97.5 \mathrm{cc}$ petrol engine, to work it as a biogas-hydrogen fuel spark ignition engine. Hydrogen added in small amounts by HHO generator (hydroxy) kit to decrease concentration of $\mathrm{CO} 2$ in biogas power and find out the effect of $\mathrm{CO} 2$ on the performance. The experimental results show that the large quantity of $\mathrm{CO} 2$ present in biogas lowers its calorific value, flame velocity and flammability range compared with natural gas. So it can be utilized in an IC engine with the hydrogen.

Keywords: Biodiesel, Hydrogen, SI engine, HHO, Bio fuel

\section{INTRODUCTION}

In the 20th century, world energy usage has increased significantly due to the effect of industrialization, and this increase in usage has resulted in limited petroleum reserves, such as the 1970's oil crisis [1]. Most of the energy used in the world is supplied by fossil fuels. Burning of the fossil fuels generates waste materials, mainly emissions to the atmosphere in the form of combustion fuel gases and dust, as well as some ash. These waste materials have hazardous effects on the environment, some of them locally, others with more widespread or even global impact. Not only does the continued use of large amounts of fossil fuels pose a serious threat to the environment, but also the fuels themselves are finite in quantity. There are debates amongst experts about the extractable amount of fossil fuels. General opinion is that in the beginning of the 21 st century almost half of the fossil fuels had already been consumed. The known worldwide reserves of petroleum are 1000 billion barrels and these Petroleum reserves are predicted to be consumed in about 40 years. Another problem with petroleum is the emission of pollutants, such as $\mathrm{CO} 2, \mathrm{NOx}, \mathrm{CO}$ and hydrocarbons (HC). So, the world had to search for other sources of fuel and now a day the most useful and eco-friendly source are gaseous fuels.Gaseous fuels have wide flammability limits and can easily form a homogeneous mixture with air for good combustion. Thus they will lead to very low levels of pollutants and can be effectively utilized in both spark ignition (SI) and compression ignition (CI) engines. Moreover, gaseous fuels have high hydrogen to carbon ratios. Thus very low $\mathrm{CO} 2$ emissions are possible when they are used in IC Engines. Natural gas and Liquefied Petroleum Gas (LPG) are the readily available petroleum-based fuels, while hydrogen, biogas and producer gas can be obtained from renewable sources. Renewable fuels will not affect the net $\mathrm{CO} 2$ in the environment.Biogas is an attractive source of energy for rural areas. It can be produced from cow dung and other animal waste and also from plant matter such as leaves and water 
hyacinth - all of which are renewable and available in the countryside. Also called "gobar gas", it is produced by bacteria, which breaks down organic material under air less conditions. This process is called "anaerobic digestion". The composition of biogas, depending on the feed material and the method of digestion, usually lies within the following ranges: $50-70 \%$ methane $(\mathrm{CH} 4), 25-50 \% \mathrm{CO} 2,1-5 \%$ $\mathrm{H} 2,0.3-3 \% \mathrm{~N} 2$ and various minor impurities, notably hydrogen sulphide (H2S). Hydrogen sulphide provides the biogas its bad odder. The presence of carbon dioxide in the biogas reduces the burning velocity which ultimately affects the performance of the engine. Percentage of methane and carbon dioxide in biogas varies with the maturities of feed stock, temperature, water content, loading rate of raw material and bacterial actions. A biogas can act as a promising (future excellence) alternative fuel by substituting (to put in place of) considerable amount of fossil fuels. Biogas, produced by the anaerobic fermentation of cellulosic biomass materials, is a clean fuel to run internal combustion engines [2].

\section{Applicability of Biogas And Hydrogen In Ic Engines}

\section{A. Why Biogas will useful in IC Engines?}

We know that the economy of India depends to a large extent on the wheels of transport. However, because of a high investment cost and a heavy infrastructure, only fifty percent of the biogas production is upgraded, and the natural gas replacement is very low. This renewable energy is already used for heat and electricity production, but the best upgrading solution of this clean energy should be the injection into the natural gas grid or the production of vehicle fuel. Biogas containing more than $45 \%$ carbon dioxide caused harsh (rough or unpleasant to the senses) and irregular running of the engine. Similar results were obtained by others, in which increased exhaust emission of the unburned fuel was found in the region of $45-50 \%$ carbon dioxide [3]. The large quantity of $\mathrm{CO}_{2}$ present in biogas lowers its calorific value, flame velocity and flammability range compared with natural gas. The self-ignition temperature of biogas is high and hence it resists knocking which is desirable in SI engines. Thus biogas has a high anti-knock index and hence biogas engine can use high compression ratios, which can lead to improvement in thermal efficiency.
Biogas cannot be used to run an IC engine directly on account of its high self ignition temperature. However, it can be utilized in an IC engine with the dual fuelling approach. The dual fuel engine is basically a modified IC engine. In this case, a mixture of air and biogas or other gaseous fuel is sucked into the engine, compressed and then ignited by a spray of fuel with a low self-ignition temperature like diesel, vegetable oil or biodiesel, which is called a pilot fuel [4]. Dual fuel operation always needs a small amount of pilot fuel for ignition.

\section{B. Why and how hydrogen will inject?}

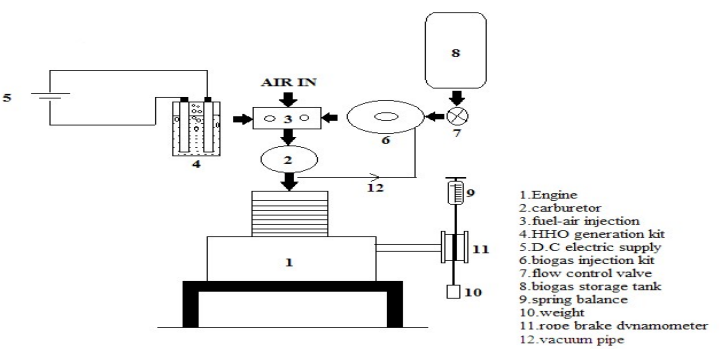

Hydrogen is also renewable source, which produces in small amount by use of HH0 Generator, and directly inject into engine with low calorific biogas. Water contains two Hydrogen atoms $\left(\mathrm{H}_{2}\right)$ and one Oxygen molecule. In a combined form they are the abundant resource known as water. A HHO Generator is a device that uses electrolysis to convert water into two parts Hydrogen and one part Oxygen. This gas, also known as Brown's Gas, is a very clean burning powerful fuel. Through the simple process of running electric current through the water, the atoms 'split' back into their original elemental forms. This process is known as electrolysis. Electrical current runs through the water and all the Hydrogen atoms run toward the negatively charged electrode, while all the oxygen atoms move toward the positive electrode.

\section{Theoretical Considerations, Experiment Setup and Procedure}

\section{A. Theoretical Consideration}

S. Orhan Akansu (2007) and E. Porpatham (2012) conclude that presence of up to $30 \%$ carbon dioxide in biogas improved the engine performance as compared to the same running with natural gas ( $96 \%$ methane) but percentage of methane and carbon dioxide in biogas varies with the maturities of feed stock, temperature, water content, loading rate of raw material and bacterial actions [4]. 
Theoretical study shows that concentration of $\mathrm{CO} 2$ in biogas decreases and increases combustible component of fuel by injecting hydrogen with biogas. Also, hydrogen is cleanest world fuels which add with fossil fuel in engine to increase calorific value, flame velocity, flammability range of fuel.

\section{TABLE I : MASS FRACTION OF COMPONENTS}

\begin{tabular}{|l|l|l|l|l|}
\hline & $\begin{array}{l}\text { mass } \\
\text { fraction } \\
\text { of } \\
\text { carbon } \\
\end{array}$ & \multicolumn{3}{|l|}{$\begin{array}{l}\text { mass fraction } \\
\text { of combustible } \\
\text { dioxide }\end{array}$} \\
\cline { 2 - 5 } & & $\mathrm{CH}_{4}$ & $\mathrm{H}_{2}$ & TOTAL \\
\hline very bad & 0.4 & 0.52 & 0.015 & 0.535 \\
\hline good biogas & 0.3 & 0.62 & 0.015 & 0.635 \\
\hline biogas injected & 0.307 & 0.4 & 0.242 & 0.642 \\
\hline
\end{tabular}

\section{EXPERIMENTAL SET UP}

The experimental apparatus included compressor and biogas storage tank, biogas purification, internal combustion engine and its attachments and H.H.O. generation kit, biogas injection kit, fuels-air injection, dynamometer as shown in Fig. 1. Sufficient biogas was filled up in biogas storage tank by use of compressor and distilled water was filled up in HHO generation kit up to required height withsalt.D.C. Power was supplied to $\mathrm{HHO}$ kit and $\mathrm{HHO}$ gas was supplied to fuel-air injector, also connected biogas storage tank and vacuum pipe with biogas injectionkit.

\section{EXPERIMENTAL PROCEDURE}

With starting engine and increasing the speed of engine and it is measured by tachometer and note down spring balance scale at different speed. Mass of biogas and $\mathrm{HHO}(\mathrm{lit} / \mathrm{sec})$ were measured and calculated from brake power, brake thermal efficiency and specific fuel consumption at different speed.

\section{A. Mathematical Modelling}

\section{1) Brake Power(kw)}

$\mathrm{Bp}=\quad \pi$. Deff $. \mathrm{N} .(\mathrm{W}-\mathrm{S}) / 60000.0 .3$

Here,

Deff $=(D p+D r)$, Effective diameter of pulley $(m) D p$ $=$ diameter ofpulley
$\mathrm{Dr}=$ diameter of rope

$\mathrm{W}=$ Total mass supported at rope $(\mathrm{kg}) \mathrm{S}=$ spring balance $(\mathrm{kg})$

$\mathrm{N}$ = pulley speed, $\mathrm{RPM}$

Assuming dynamometer efficiency $30 \%$ brake power of the engine.

\section{2) Mass of the petrol fuel $(\mathrm{kg} / \mathrm{hr})$}

$\mathrm{Mfp}=\zeta \mathrm{p} .10-5.3600 / \mathrm{tp}$

here,

$\zeta \mathrm{p}=$ density of petrol $\left(\mathrm{kg} / \mathrm{m}^{3}\right)$

$\mathrm{tp}=$ time taken for consuming $10 \mathrm{ml}$ of petrol (sec)

\section{3) Mass of gases fuel(kg/hr)}

$\mathrm{Mfg}=\mathrm{mb}+\mathrm{mh}$

Here, $\mathrm{mb}=$ mass of biogas $(\mathrm{kg} / \mathrm{hr})$

$\mathrm{mb}=\zeta \mathrm{b} \cdot 10-3.3600 / \mathrm{tb}$

Here, $\zeta \mathrm{b}=$ density of biogas $(0.85 \mathrm{~kg} / \mathrm{m} 3)$

$\mathrm{tb}=$ time consume for filling 1 lit $(\mathrm{sec})$

Here, $\mathrm{mh}=$ mass of hydrogen $(\mathrm{kg} / \mathrm{hr})$

$\mathrm{mh}=\zeta \mathrm{h} .10-3.3600 /$ th

Here, $\zeta \mathrm{h}=$ density of hydrogen $(0.089 \mathrm{~kg} / \mathrm{m} 3)$

th = time consume for filling 1 lit $(\mathrm{sec})$

\section{4) Specific fuel consumption ( $\mathrm{kg} / \mathrm{kw} \cdot \mathrm{hr}$ )}

$$
\mathrm{SFC}=\mathrm{mf} / \mathrm{Bp}
$$

Here, $\mathrm{mf}=$ mass of fuel $(\mathrm{kg} / \mathrm{hr})$

\section{5) Brake thermalefficiency}

As the power output may be indicated by power or brake power, therefore thermal efficiency may be expressed as indicated thermal efficiency or as brake thermal efficiency.

$$
\mathrm{BTE}=\mathrm{Bp} .3600 .100 / \mathrm{mf} . \mathrm{CV}
$$

Where, $\mathrm{CV}=$ calorific value for fuel $(\mathrm{kj} / \mathrm{kg}) \mathrm{mf}=$ fuel consumption $\mathrm{Kg} / \mathrm{hr}$ 


\section{RESULTS AND DISCUSSION}

TABLE I: OBSERVATION TABLE FOR PETROL FUEL ENGINE

\begin{tabular}{|c|c|c|c|c|c|c|c|c|}
\hline $\begin{array}{l}\text { Sr. } \\
\text { No. }\end{array}$ & $\begin{array}{l}\text { Speed } \\
\text { (RPM) }\end{array}$ & $\begin{array}{l}\text { Effective } \\
\text { diameter of pulley, } \\
\text { Deff }\end{array}$ & $\begin{array}{l}\text { Total mass } \\
\text { support }\end{array}$ & $\begin{array}{l}\text { Spring } \\
\text { balance, } \\
\mathrm{S}(\mathrm{kg})\end{array}$ & $\begin{array}{l}\text { Density } \\
\text { petrol, } \\
\text { \%p (kg/m }\end{array}$ & $\begin{array}{l}\text { of } \begin{array}{l}\text { Time for } \\
\text { consume } \\
10 \mathrm{ml}\end{array}\end{array}$ & $\begin{array}{l}\text { Mass of fuel, } \\
\text { mfp }\end{array}$ & $\begin{array}{l}\text { calorific value } \\
\text { for fuel, } \mathrm{CV}\end{array}$ \\
\hline & & & & & & & $(\mathrm{kg} / \mathrm{hr})$ & \\
\hline 1 & 620 & 0.065 & 9.9 & 1.3 & 772 & 102 & 0.272 & 42000 \\
\hline 2 & 865 & 0.065 & 9.9 & 2 & 772 & 83 & 0.336 & 42000 \\
\hline 3 & 1115 & 0.065 & 9.9 & 3 & 772 & 76 & 0.365 & 42000 \\
\hline 4 & 1956 & 0.065 & 9.9 & 4.5 & 772 & 65 & 0.427 & 42000 \\
\hline
\end{tabular}

TABLE II: RESULT TABLE FOR PETROL FUEL ENGINE

\begin{tabular}{|l|l|l|l|}
\hline \multirow{2}{*}{ r No } & BP & Specific Fuel consumed. & Brake thermal efficiency. \\
\cline { 2 - 4 } & $(\mathrm{kw})$ & (kg/kw.hr) & $(\%)$ \\
\hline 1 & 0.589 & 0.462 & 18.55 \\
\hline 2 & 0.76 & 0.442 & 19.39 \\
\hline 3 & 0.856 & 0.427 & 20.1 \\
\hline 4 & 1.17 & 0.365 & 23.46 \\
\hline
\end{tabular}

TABLE III : OBSERVATION TABLE FOR HHO \& BIOGAS FUELS ENGINE

\begin{tabular}{|c|c|c|c|c|c|c|c|c|}
\hline \multirow[t]{3}{*}{ Sr. No. } & \multirow[t]{3}{*}{$\begin{array}{l}\text { Speed } \\
\text { (RPM) }\end{array}$} & \multirow{3}{*}{$\begin{array}{l}\text { Effective } \\
\text { diameter } \\
\text { pulley(Deff) }\end{array}$} & \multirow{3}{*}{$\begin{array}{l}\text { Spring } \\
\text { of balance } \\
(\mathrm{kg})(\mathrm{S})\end{array}$} & \multirow{3}{*}{\multicolumn{2}{|c|}{$\begin{array}{l}\text { mass in of mass tif } \\
\text { biogas, mb } \mathrm{HHO}, \\
(\mathrm{kg} / \mathrm{hr}) \\
\text { eveloph } \\
(\mathrm{kg} / \mathrm{hr})\end{array}$}} & \multirow{2}{*}{$\begin{array}{l}\text { offuass } \\
\text { mh }\end{array}$} & $\frac{9}{2}$ & \multirow{2}{*}{$\begin{array}{l}\text { calorific value for fuel } \\
(\mathrm{KJ} / \mathrm{kg})\end{array}$} \\
\hline & & & & & & & & \\
\hline & & & & & & $\overline{(\mathrm{kg} / \mathrm{hr})}$ & & 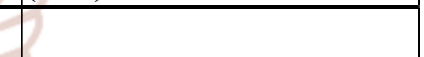 \\
\hline 1 & 590 & 0.065 & 1 & 0.4552 .456 & 0.095 & 0.55 & & 30000 \\
\hline 2 & 810 & 0.065 & 1.9 & 0.566 & 0.095 & 0.661 & $F$ & 30000 \\
\hline 3 & 1095 & 0.065 & 2.5 & 0.641 & 0.095 & 0.736 & $\angle$ & 30000 \\
\hline 4 & 1780 & 0.065 & 4 & 0.842 & 0.095 & 0.937 & 7 & 30000 \\
\hline
\end{tabular}

TABLE IV: RESULT TABLE FOR HHO \& BIOGAS FUELS ENGINE

\begin{tabular}{|l|l|l|l|}
\hline $\begin{array}{l}\text { Sr. } \\
\text { No. }\end{array}$ & BP & $\begin{array}{l}\text { Specific } \\
\text { Fuel } \\
\text { consumed. }\end{array}$ & $\begin{array}{l}\text { Brake thermal } \\
\text { efficiency. }\end{array}$ \\
\cline { 2 - 4 } & $(\mathrm{kw})$ & $(\mathrm{kg} / \mathrm{kw} \cdot \mathrm{hr})$ & $(\%)$ \\
\hline 1 & 0.584 & 0.941 & 12.74 \\
\hline 2 & 0.721 & 0.916 & 13.08 \\
\hline 3 & 0.901 & 0.816 & 14.69 \\
\hline 4 & 1.168 & 0.802 & 14.95 \\
\hline
\end{tabular}

\section{Effect of Bp on Specific Fuel consumption:}

At the same brake power, the SFC for petrol is less than biogas and $\mathrm{HHO}$ due to high calorific value of fuel. The specific fuel consumption is higher at low brake power for both fuels; the SFC continually decreases with increase of brake power for petrol engine but for HHO and BIOGAS engine SFC nearly remains constant above brake power 0.9 .

\section{Effect of BP on Brake Thermal Efficiency}

brake thermal efficiency of petrol engine is higher compared to $\mathrm{HHO}$ and biogas engine at same brake power. Brake thermal efficiency of both fuel engines increases with increase of brake power, but above brake power 0.9 the brake thermal efficiency not much affected with increase of brake power.

\section{CONCLUSION}

Based on this experimental work on the use of hydrogen to enhance the combustion characteristics of biogas, the following conclusions are drawn. SFC 
decreases with increase in brake power for both fuels, $\mathrm{SFC}$ of biogas and HHO fuel engine is higher than petrol engine due to low calorific value of fuel. BTE increases with increase in brake power for both the cases but the BTE of biogas is somewhat lower compared to petrol engine because the SFC of petrol is lower.

\section{REFERENCES}

1. M. Canakci, "Combustion characteristics of a turbocharged DI compression ignition engine fueled with petroleum diesel fuels and biodiesel", Bio resource Technology, 98(2007): 1167.

2. E. Porpatham, A. Ramesh and B. Nagalingam, "Investigation on the effect of concentration of methane in biogas when used as a fuel for a spark ignition engine", Fuel, 87(2008): 1651.

3. S. Bari, "Effect of carbon dioxide on the performance of biogas/diesel dual-fuel engine", School of Mechanical Engineering, University Sains, Malaysia, (1996): 1007.
4. E. Porpatham, A. Ramesh and B. Nagalingam,"Effect of compression ratio on the performance and combustion of a biogas fuelled spark ignition engine", Fuel, 95(2012): 247.

5. S.S.Kapdi,"Biogas scrubbing,compression and storage: perspective and prospectus in Indian context Centre for Rural Development and Technology", Indian Institute of Technology, New Delhi, India. (2004).

6. Keyur patel," Experimentation study on spark ignition Engine by hydrogen with biogas fuel", VIER Journal of Engineering Research, Issue -4 (2017), pp 79-82.

7. European commission, Energy for future, Renewable sources of energy white paper for a community strategy and action plan, com, Brussels (1997). 